\title{
Edible Insects: Benefits and Potential Risk for Consumers and the Food Industry
}

\author{
Konstantina Papastavropoulou 1, Anastasia Koupa 1, Evangelia Kritikou 1, Marios Kostakis 1, \\ Charalampos Proestos 1,*iD
}

1 Laboratory of Food Chemistry, Department of Chemistry, School of Sciences, National and Kapodistrian University of Athens, Athens, Greece; dinapapa@chem.uoa.gr (K.P.); anastasia.koup@gmail.com (A.K.); evkritik@chem.uoa.gr (E.K.); makostak@chem.uoa.gr (M.K.); harpro@chem.uoa.gr (C.P.);

* Correspondence: harpro@chem.uoa.gr (C.P.);

Scopus Author ID 6507389364

Received: 31.07.2021; Revised: 9.09.2021; Accepted: 12.09.2021; Published: 17.10.2021

\begin{abstract}
Proper protein production is a serious challenge for the future. Insects represent an innovative food source and are extremely nutritious, as they have a high content of proteins and a well-balanced nutrient profile. This study focuses on the positive reasons for the use of insects as a food source and examines the contribution of insects to the human diet and the growing demand for cheap proteins in the food industry. In addition, in the present study, analyzes were performed to determine the nutritional value of mealworms and commercially available cricket flour. Moisture, ash, Total Energy Value, proteins, amino acids, fat, fatty acid profiles, carbohydrates, dietary fiber, and minerals were identified. According to the results, the samples have a high protein content and high concentrations of various amino acids (especially the essential amino acids). They also have a well-balanced fatty acid profile, high in polyunsaturated, monounsaturated fatty acids and many minerals. The main tasks are the dissemination of knowledge, the change of the process for obtaining edible insects, the development of the edible insect food industry, the expansion of the composition of already used insects, and the future conduct of research on risks to human health.
\end{abstract}

Keywords: insects; edible insects; insects as food; cricket flour; mealworms; nutritional value of insects.

(C) 2021 by the authors. This article is an open-access article distributed under the terms and conditions of the Creative Commons Attribution (CC BY) license (https://creativecommons.org/licenses/by/4.0/).

\section{Introduction}

It is known that both the ancestors of Homo sapiens and the primitive communities used insects as a food source [1]. Before humans acquired tools for hunting and gathering food, insects were an important part of their diet, as evidenced by the coprolites of ancient humans [2-4]. In the Near East and China, they ate insects thousands of years ago [5,6]. While in many parts of the world (Asia, Africa, America), insects are still part of their diet today [7]. However, attitudes towards entomophagy are determined by many factors (psychological, social, religious, anthropological, etc.) [8], while the first known reference to entomophagy in Europe is present in work by Aristotle [9]. Insects were also consumed by the ancient Romans and peoples of various religions such as Christians, Jews, Judaists, and Islamists [6]. There are many references to the use of insects as food in literary works of the Middle Ages and later years $[6,10]$. In modern western society, the use of insects as food was examined by DeFoliart [11]. Currently, 2 billion people in 113 countries consume insects [12]. 
The problem of lack of food resources has always existed among human societies due to the limitation of plants and animals. As the world's population grows, humanity's need for food, especially animal protein, has also increased [13]. The complexity of this issue is due to the fact that while arable land and pastures have expanded significantly since the early 1960s, the number of areas suitable for extensive agricultural production is declining. Therefore, the increase in animal protein production is likely to be accompanied by further environmental degradation, especially in tropical countries [14, 15]. For example, the establishment of livestock farms resulted in the deforestation of 38\% of the land in Brazil from 1966 to 1975 [16]. Insect farming, which consists of small livestock businesses, provides or complements the growing demand for natural proteins [17]. Insects can cost less than animal protein for poor rural communities, and consuming them has prevented many cases of malnutrition. The adoption of insects as a food source can be based on three reasons, human health, environmental factors, and socio-economic benefit $[6,18,19]$.

Edible insects have a higher protein content on a mass basis than other animal and plant foods (beef, chicken, fish, soy, maize) [20]. A good example is the mopane worm Gonimbrasia belina (South Africa), which contains 64\% protein, higher than meat and fish [21]. In addition, many insect species provide a good source of protein, minerals, vitamins, and energy, are high in essential fatty acids and have adequate calcium, iron, and zinc. The nutritional composition of edible insects can vary greatly depending on the species, the life stage of the insects, the environment, and the diet. In Nigeria, for example, grasshoppers fed on bran, which contains high levels of essential fatty acids, have almost twice the protein content of those fed on maize [6].

Environmental benefits include specific emissions of greenhouse gases and ammonia, land area, and water consumption from insect breeding, which are much lower than most animals [22-24]. In addition, insects are cold-blooded animals; their efficiency in converting food into protein is very high [22, 23, 25, 26]. The production of $1 \mathrm{~kg}$ of animal protein in animal husbandry requires $2.5,5$, and $10 \mathrm{~kg}$ of feed for chicken, pork, and beef, respectively. $[27,28]$. While the demand for insects is much lower since the production of $1 \mathrm{~kg}$ live weight of common crickets, Acheta domesticus requires only $1.7 \mathrm{~kg}$ of feed [28], while products that are not consumed directly by humans can be used as animal feed.

The economic and social factors that make insect farming more desirable than animal husbandry are that insect harvesting and breeding require low technology and capital investment choices, even for the poorest sections of society. The cultivation of insects provides living opportunities to both the urban and the rural population. Insects have short life cycles, fast returns on investment, and high economic returns. Also, huge sums of money are spent in the world every year to protect agricultural plants, especially cereals, from insects. The paradox of the situation is that cereal crops contain no more than $14 \%$ protein, while other diets (insects), which contain up to $75 \%$ of high-quality animal protein, are destroyed [29]. Harvesting insects for food would be an ideal alternative to increase food production and reduce the pressure of pests in cultivated areas [30]. The advantages are the increased productivity of plant foods, the provision of additional food resources (insects), and the improved health and environmental benefits due to the reduced use of insecticides [31]. In addition, insects have a high reproduction rate at a very young age, producing larger amounts of valuable protein than traditional meat and dairy farms. All these reasons make the cultivation of insects more profitable [22]. 
The most commonly consumed insects are the crickets (Acheta domesticus, Gryllus assimilis, Gryllodes sigillatus, G. Bimaculatus, G. locorojo), the honeycomb moth (Galleria mellonella), the longhorn grasshopper (Ruspolia differens), the migratory locust (Locusta migratoria), the mealworms (Tenebrio molitor, Alphitobius diaperinus, Zophobas atratus), the housefly (Musca domestica), and the black soldier fly (Hermetia illucens) [2]. 88\% of edible insects are terrestrial, while $12 \%$ are aquatic [31]. Insects belonging to different orders are consumed at different life cycle stages $[6,32,33]$. The variety and abundance of insects are usually higher in the subtropical and tropical regions of the world, so most people who consume insects are mainly in these regions [6]. China, Japan, and Mexico are the only countries in all or part of the temperate zone where entomophagy is practiced in higher proportions [34].

Food preferences are formed in childhood, and the older one gets, the harder it is to change them. Many people do not like to use insects as food, considering that eating insects are disgusting $[19,35,36]$. However, most edible insects are herbivores that feed mainly on fresh plant leaves or wood [37]. For this reason, they are cleaner and healthier than crabs or lobsters, which eat carrion and are sometimes collected from contaminated aquatic systems [38]. This attitude is nothing but a prejudice because, over the years, many old unusual foods have become traditional (frogs, lobsters) [12, 39].

Increased interest in edible insects is considered a response to the adverse effects of globalization [40]. Currently, a large part of humanity is concerned about the environment. Numerous studies have shown that novel foods gain popularity in the section of society before they spread further [35]. The environmental part of society can become such a part. Finally, training, promoting the benefits of consuming insects, properly treating insects before eating to improve their organoleptic properties, cost-effectiveness, regulation, and transparency of information to consumers will help the successful globalization of entomophagy [19].

The three ways in which edible insects can be obtained are wild harvest (92\%), semidomestication (6\%), and agriculture (2\%) [31]. Insect farming is a recent and rarely used method of producing edible insects. Insects are raised in captivity isolated from their natural populations, and their living conditions, diet, and food quality are monitored. The cultivation of insects for human consumption has occurred in tropical and temperate countries (Thailand, Netherlands, France) [41-43]. Production technologies by species are described in publications $[2,44]$. In temperate zones, insects are bred mainly for animal consumption. The most common farmed insects are mealworms (Tenebrio molitor) [22]; other farmed insects include crickets and locusts.

The demand for animal feed is increasing as the growing human population puts pressure on natural resources and the ecosystem to produce animal protein [45]. Many different animals, both farm and pet, feed on insects (cats, dogs, pigs, birds, fish, reptiles) [14, 46-52]. Insect species most suitable for mixed feed production are black soldier fly larvae (Hermetia illucens), common fly larvae (Musca domestica), silkworms (Anaphe panda, Bombyx mori), crickets (Gryllodes sigillatus, Gryllus bimaculatus, Acheta domesticus), worms (Zophobas atratus, Tenebrio molitor, Alphitobius diaperinus), the locusts (Locusta migratoria), the sun beetles (Pachnoda marginata peregrina), the wax moths (Galleria mellonella), the cockroaches (Blaptica dubia, Nauphoeta cinerea) and termites (Kalotermes flavicollis) [50, 53-58]. In addition, the collection of agricultural insect pests for use as food reduces the consumption of harmful pesticides by humans.

Insects must be properly treated before being eaten by animals or humans. The following variants of insect treatment before eating have been reported in the bibliography: 
consumption of whole insects, processing into granules or paste, and extraction by insects of specific food ingredients [59]. When insects are consumed unchanged, the traditional preparation methods are steaming, boiling, baking, frying, washing, smoking, and chutney processing $[40,60]$. In countries where people have eaten insects for millennia, eating habits have shifted to western diets $[6,61]$. Consumption of intact insects is more typical of tropical countries, where insects are usually eaten whole. However, in insects such as locusts, grasshoppers, and adult beetles, certain parts of their body (wings, legs) are removed before consumption [59]. Many insect cookbooks have already been published [62-65]. Processing in granular and paste forms is most often used in countries where consumers are not accustomed to eating whole insects. For example, Europe produces typical foods from homogenized insects (patties, pasta, and bread). Grinding or milling are normal methods for processing large numbers of products and are often used for reprocessing insects [66]. In these forms, they are better accepted by consumers. In these forms, they are better accepted by consumers. The resulting powders and pastes are usually added to other low-protein products to increase their nutritional value [63]. This direction of insect food use is successfully developed in many countries, developing new technologies [6, 43, 67]. Insect extraction of certain food ingredients is preferable in societies where the use of insects for food does not have a long tradition. Often, people are receptive to an idea of the nutritional value of insects but prefer to be blind to what they eat. However, at times it has created problems for people who have allergic reactions [26]. In most cases, proteins are extracted from insects, but fats, chitin, minerals, and vitamins can also be extracted. Until now, the procedures for exporting individual food ingredients have been very expensive, and further development of cost-effective and practical methods of their commercial use is required [6].

The use of insects as food brings many advantages. However, not all insects are safe to eat. In developing and less developed countries, legislation is almost non-existent. In developed countries, on the other hand, food complaint actions are formulated and carried out [68-70]. Microbial, chemical, physical, allergenic, parasitic, and toxicological hazards must be considered when selecting insects for human consumption. There are also risks due to the consumption of insects at the inappropriate developmental stage or to incorrect culinary preparation. Numerous studies have identified various hazards to human health due to the use of insects in food $[9,18,19,71-76]$. Many researchers have reported allergic reactions after consuming various insects; however, no deaths from insects have been reported [77-80].

Based on the above, we conclude that entomophagy has many benefits that we want to promote and communicate through this research and highlight the risks and conditions for the proper and safe use of insects as a food source for humans.

\section{Materials and Methods}

The samples analyzed were mealworms (larvae of Tenebrio molitor) obtained from Terra Insecta and commercially available cricket flour. Mealworms ate mainly wheat bran and small amounts of carrots and potatoes. For each sample, approximately $50 \mathrm{~g}$ of live insects and crickets flour, respectively, were transferred for analysis of moisture, fat, protein, ash, total fiber, minerals, amino acids, and fatty acids. The insects were transported alive and kept refrigerated upon receipt until analyzed. All insects were fasted for about 24 hours prior to analysis to reduce the effects of food remaining in the gut. The mealworms were placed in a crushed conical flask, which after being closed with a lid, was placed in an oven at $110^{\circ} \mathrm{C}$ for 48 hours. This procedure was done to avoid creating stress. Then, after being killed due to lack 
of oxygen and the presence of heat, they were homogenized in a food processor, so we got a kind of flour, while the cricket flour sample was used as-is.

Humidity and ash were determined according to AOAC 934.01 and AOAC 942.05, respectively. Total fat was determined based on the ISO 1443: 1973 method. The fatty acid profile was determined by the internal gas chromatography method with a flame ionization detector based on ISO-12966 2. Total fiber was determined based on AOAC 993.21 by a combination of enzyme and gravimetric methods. Proteins were determined by the Kjeldahl method. Amino acids were determined by the internal HILIC-MS / MS method. Carbohydrates were calculated by subtracting the percentage of fat, protein, ash, and moisture from 100 . The minerals were measured in MP-AES, an internal method of atomic emission spectrometry with inductively coupled nitrogen plasma, while the phosphorus determination was done according to REGULATION (EC) 152/2009. Finally, the Total Energy Value (KJ / 100 g, Kcal / 100 g) was calculated according to the Food and Beverage Code, article 11a. All comparisons were adjusted for insect energy density (nutrients / $100 \mathrm{~g}$ on the dry sample).

The reagents used were Sodium Phosphate monobasic monohydrate $\left(\mathrm{NaH}_{2} \mathrm{PO}_{4}\right)$ and Potassium Hydroxide $(\mathrm{KOH})$ from Honeywell, Fluka. Sodium Phosphate dibasic minimum $\left(\mathrm{Na}_{2} \mathrm{HPO}_{4} 99 \%\right)$, Phosphoric Acid $\left(\mathrm{H}_{3} \mathrm{PO}_{4}\right)$, Methane sulfonic acid, and TDF-100A Kit $(\alpha-$ amylase, protease, amyloglucosidase, celite) by Sigma Aldrich. Nitric Acid $\left(65 \% \mathrm{HNO}_{3}\right)$ from Macron Fine Chemicals. Hydrochloric Acid ( $\mathrm{HCl} 37 \%)$, Sulfuric Acid $\left(\mathrm{H}_{2} \mathrm{SO}_{4},>=95 \%\right)$, Ammonium formate and Acetonitrile $(\mathrm{ACN})$, Methanol and Diethyl ether $(>=99.5 \%)$, from Fisher Chemical. Sodium Hydroxide, Boric Acid $\mathrm{H}_{3} \mathrm{BO}_{3}$, and Sodium Sulfate anhydrous $\mathrm{Na}_{2} \mathrm{SO}_{4}$ from lach: ner. Cooper (II) Sulfate pentahydrate $\left(\mathrm{CuSO}_{4} * 5 \mathrm{H}_{2} \mathrm{O} 99 \%\right)$ from Alfa Aesar. Potassium Sulfate $\left(\mathrm{K}_{2} \mathrm{SO}_{4}\right)$ and Ethanol $99.8 \%$ from Acros Organics. Petroleum Ether, Hydrogen peroxide solution $30 \%,\left(\mathrm{H}_{2} \mathrm{O}_{2}\right)$, Formic acid and Hexane from Carlo Erba Reagents (Dasit Group).

The instruments used were a calibrated four-decimal analytical balance (Shimadzu AUW320), an incinerator (Gallenkamp Furnace, Muffle furnace made in England), a Rotary (Lab Tech EV 311H), a Kjeldahl digester (Velp Scientifica DK6 Heating Digester), a Kjeldahl distillation apparatus (Velp Scientifica, UDK 139), a Gas chromatography (Varrian 450-GC), a Microwave Plasma Atomic Emission Spectrometry (4210 MP-AES, Agilent Technologies), a thermoreactor (WTW CR 3200), a microwave digestion system (Mars X-PRESS, CEM), a spectrophotometer (DR12010, HACH), a centrifuge (Neya-8, NEYA) and a HILIC-MS / MS (TSQ Quantum Access, Thermo Fisher Scientific).

\subsection{Humidity - Ash}

The humidity method is based on calculating the difference in weight of the sample after heating it to $110^{\circ} \mathrm{C}$ for 24 hours. The method for the ash is based on the calculation of the difference in weight of the sample after burning in a flame until it stops emitting smoke and firing at $550{ }^{\circ} \mathrm{C}$ for 4 hours. For each sample, a duplicate is performed in both methods.

\subsection{Fat.}

A quantity of samples is extracted with suitable solvents after boiling with hydrochloric acid. After evaporation of the ether, the fat percentage of the sample is calculated. Specifically, $1.0 \mathrm{~g}$ of the sample is weighed in a mozoniere, $2 \mathrm{~mL}$ of ethanol is added and stirred manually and with vortex. Add $10.0 \mathrm{~mL} \mathrm{HCl} \mathrm{8.3 \%} \mathrm{(v/v)} \mathrm{and} \mathrm{stir} \mathrm{with} \mathrm{vortex.} \mathrm{Place} \mathrm{the} \mathrm{mozoniere} \mathrm{in} \mathrm{a}$ 
water bath at $70-80{ }^{\circ} \mathrm{C}$ for $40 \mathrm{~min}$. During this time, the mozoniere should be stirred every 10 minutes. It comes out of the water bath and is left to cool. Add $10 \mathrm{~mL}$ of ethanol and mix very well with the vortex. Add $25 \mathrm{~mL}$ of petroleum ether and stir manually, and with vortex, $25 \mathrm{~mL}$ of diethyl ether is added, followed by stirring manually and with vortex. The mozoniere is placed in an ultrasonic bath for $20 \mathrm{~min}$ at $25^{\circ} \mathrm{C}$. The mozoniere comes out of the water bath, and the organic layer is poured 1 st into the pre-weighed and moisture-free beaker. Then add 15 $\mathrm{mL}$ of petroleum ether, stir manually and with vortex, add $15 \mathrm{~mL}$ of diethyl ether and stir manually and with vortex. If an emulsion forms, add 1-3 $\mathrm{mL}$ of ethanol. Place the mozoniere in an ultrasonic bath for 15 minutes at $25^{\circ} \mathrm{C}$. Pour the organic layer again into the pre-weighed glass. Finally, the previous procedure is repeated once more. The glass with the 3 extracts is then placed on a heating plate until the organic solvent evaporates. Place the glass in an oven at $110^{\circ} \mathrm{C}$ for 30 minutes and then in a dryer to cool and weigh.

\subsection{Fatty acid profile.}

After extracting the fat based on the above pretreatment, the fat is diluted with $10 \mathrm{ml}$ of hexane. Stir and then take $750 \mu \mathrm{L}$ of the sample. To this are added $100 \mu \mathrm{L} 2 \mathrm{M} \mathrm{KOH} / \mathrm{MeOH}$ and $0.2 \mathrm{~g} \mathrm{Na}_{2} \mathrm{SO}_{4}$. The solution is stirred and frozen for 20 minutes. Then, $200 \mu \mathrm{L}$ of supernatant is taken in vials, and $800 \mu \mathrm{L}$ of hexane is added. The vials are placed in the GC.

\subsection{Total dietary fiber.}

For greater accuracy, at least 4 repetitions are required for each sample, of which 2 will be used for protein determination and two for ash determination. The method is based on the determination of fiber by fat removal using petroleum ether. The sample (fat-free) is gelatinized by the addition of $\alpha$-amylase at $95^{\circ} \mathrm{C}-100^{\circ} \mathrm{C}$. Protease and amyloglucosidase are then added at $60{ }^{\circ} \mathrm{C}$ to remove the protein and starch from the sample. Ethanol is added to precipitate the soluble fiber and left to stand for $24 \mathrm{~h}$. The sample is then filtered, and the filter is rinsed with ethanol. The residue is placed in an oven for drying, where it is left for 24 hours. After drying, it is weighed, and half of the residues are analyzed for protein and the other half for ash. Total fiber is the weight of the residue after the protein and ash are removed.

\subsection{Crucibles.}

The crucibles before use are placed in an oven at $105^{\circ} \mathrm{C}$ for $1-2$ hours and then in a dryer for 30 minutes to remove any moisture. Weigh and then add $0.5 \mathrm{~g}$ of celite to each crucible. Place in the oven at $130{ }^{\circ} \mathrm{C}$ for 1-2 hours and in the dryer for 30 minutes. Weigh and store in a dryer until used.

\subsection{Sample.}

The samples are homogenized, the fat is removed by extraction with petroleum ether. That is, in a centrifuge tube, we weigh $1 \mathrm{~g}$ of sample (* 4 times). Add $25 \mathrm{ml}$ of petroleum ether, stir, centrifuge, and pour over the organic layer. Repeat this process one more time. Record the weight loss due to the removal of fat so that we can make the appropriate correction in the final content $(\%)$ of dietary fiber. 
2.7. Experimental procedure.

\subsubsection{Day 1.}

Weigh $1 \mathrm{~g}$ sample (* 4 times) of each material into beakers. Add $50 \mathrm{ml}$ of $0.08 \mathrm{M}$ Phosphate Buffer, $\mathrm{pH}$ 6.0, to each beaker. Then $0.10 \mathrm{ml}$ of $\alpha$-amylase is added and stirred well. Cover each glass with aluminum foil and place in a water bath at $95-100{ }^{\circ} \mathrm{C}$. Shake the glasses gently. Incubate for 15 minutes after the temperature rises to $95^{\circ} \mathrm{C}$. After 15 minutes, remove and allow to cool to room temperature. Add $10 \mathrm{ml}$ of $0.275 \mathrm{~N} \mathrm{NaOH}$ to each beaker and measure the $\mathrm{pH}$ of the solutions to be $7.5 \pm 0.2$ (adjust if necessary with either $0.5 \mathrm{M} \mathrm{NaOH}$ or $0.5 \mathrm{M} \mathrm{HCl}$ ). Immediately before use, prepare a $50 \mathrm{mg} / \mathrm{ml}$ solution of protease in water. Add $0.10 \mathrm{ml}$ to each beaker. Cover each glass with foil and place it in the water bath at $60^{\circ} \mathrm{C}$. Incubate for 30 minutes after the internal temperature of the glasses reaches $60^{\circ} \mathrm{C}$. After 30 minutes, they are taken out and allowed to cool to room temperature. Add $10 \mathrm{ml}$ of $0.325 \mathrm{~N}$ $\mathrm{HCl}$ to each beaker and measure the $\mathrm{pH}$ of the solutions to be $4.6 \pm 0.2$ (adjust if necessary with either $0.5 \mathrm{M} \mathrm{NaOH}$ or $0.5 \mathrm{M} \mathrm{HCl}$ ). Then, $0.10 \mathrm{ml}$ of amyloglucosidase is added to each beaker. Cover each glass with foil and place it in the water bath at $60{ }^{\circ} \mathrm{C}$. Incubate for 30 minutes after the internal temperature of the glasses reaches $60^{\circ} \mathrm{C}$. After 30 minutes, they are taken out and allowed to cool to room temperature. Add $70 \mathrm{ml}$ of $95 \%$ ethanol to each beaker. Leave the solutions overnight at room temperature to allow complete precipitation. Two blank samples are prepared, in which the course is followed completely to remove any contaminants.

\subsubsection{Day 2 .}

The crucibles that have already been prepared are placed on conical bottles connected to the vacuum supply. The celite is moistened with a little alcohol, the vacuum is opened, and the filtration of the samples begins. Each crucible corresponds to a sample. Once the sample is filtered, rinse the beaker with $20 \mathrm{ml}$ of ethanol and filter. The crucibles containing the residues are placed in an oven at $130^{\circ} \mathrm{C}$ overnight.

\subsubsection{Day 3 .}

The crucibles are taken out of the oven and placed in a dryer to cool and weigh. Two of the four replicates of each sample are used to determine protein by the Kjeldahl method, and the other two are used to determine ash. The result is obtained after the removal of proteins and ash from the residue.

\subsection{Proteins.}

The method allows the determination of the content of total nitrogenous substances in food based on the nitrogen content. The method is based on the determination of organic nitrogen, from which, using appropriate factors, it is possible to calculate the protein content of the food. This method is a special combustion method in which organic nitrogen is determined in the form of ammonia. An appropriate amount of sample is heated to high temperature, with excess concentrated $\mathrm{H}_{2} \mathrm{SO}_{4}$ in the presence of a catalyst. $\mathrm{NH}_{4} \mathrm{HSO}_{4}$ is formed, and then ammonia gas is released, which binds to excess boric acid solution in an alkaline environment. 


\subsection{Digestion (mineralization).}

Weigh $1.0 \mathrm{~g}$ of the sample and transfer it to a Kjeldahl flask. Add $7 \mathrm{~g} \mathrm{~K}_{2} \mathrm{SO}_{4}, 0.6 \mathrm{~g}$ $\mathrm{CuSO}_{4}$, and $12 \mathrm{~mL}$ concentrated $\mathrm{H}_{2} \mathrm{SO}_{4}$. At the same time, catalysts and concentrated $\mathrm{H}_{2} \mathrm{SO}_{4}$ without a sample (blank) are added to another Kjeldahl flask. Then, $5 \mathrm{~mL}$ of $\mathrm{H}_{2} \mathrm{O}_{2}$ and one boiling stone are gradually added to each flask. The cylinders are placed in the Kjeldahl burner. The heating should initially be gentle to avoid intense foaming. The heating is carefully continued for another hour at $420{ }^{\circ} \mathrm{C}$, and then the bottle with its contents is allowed to cool to ambient temperature. The combustion mixture will clear and acquire a cyan-green color.

\subsection{Ammonia distillation.}

Prepare for each sample and blank from a conical flask with $30 \mathrm{~mL}$ of $10 \mathrm{~g} / \mathrm{L}$ boric acid solution. The digested sample is transferred to the Kjeldahl distillation apparatus, and the corresponding conical flask with boric acid is placed at the bottom of the freezer. The device automatically takes $50 \mathrm{~mL}$ of $35 \% \mathrm{NaOH}$ solution and $50 \mathrm{~mL}$ of distilled water and adds them to the digested sample. Then the color changes from cyan-green to black. When the procedure is completed, titration is performed with $0.5 \mathrm{M} \mathrm{HCl}$ solution. At the equivalent point, we observe a color change from dark green to red.

\subsection{Determination of macro ( $\mathrm{Ca}, \mathrm{Mg}, \mathrm{K}, \mathrm{Na}, \mathrm{P})$ and micro $(\mathrm{Zn}, \mathrm{Fe}, \mathrm{Cu}, \mathrm{Mn})$ elements.}

\subsubsection{Microwave digestion.}

$0.5 \mathrm{~g}$ of sample was weighed directly in the digestion tube. Afterward, $7 \mathrm{~mL}$ of ultrapure water, $1 \mathrm{~mL}$ of $\mathrm{HNO}_{3}$, and $2 \mathrm{~mL}$ of $\mathrm{H}_{2} \mathrm{O}_{2}$ were added. The mixture was kept calm for $30 \mathrm{~min}$. The vessels were placed in the microwave digestion system (Mars X-PRESS, CEM). The program of digestion was the following: (a) a ramp of 5 min to reach $180^{\circ} \mathrm{C}$ and $800 \mathrm{~W}$ and stays in these conditions for $10 \mathrm{~min}$, (b) a ramp of $5 \mathrm{~min}$ to reach $180^{\circ} \mathrm{C}$ and $1600 \mathrm{~W}$, and stays in these conditions for $5 \mathrm{~min}$. In the next step, the sample was allowed to be cooled at room temperature. Then, the mixture was transferred into a centrifuge tube and diluted with ultrapure water to $50 \mathrm{~mL}$.

\subsubsection{Instrumentation - measurement.}

In the case of $\mathrm{P}$, a photometric determination was performed based on Regulation (EC) No 152/2009 to determine total phosphorus except for the step of preparation of the solution. The measurement was made at $430 \mathrm{~nm}$ using a spectrophotometer (DR12010, HACH).

Regarding the other elements (Ca, Mg, K, Na, Zn, Fe, Cu, Mn), the samples were measured with Microwave Plasma Atomic Emission Spectrometry (4210 MP-AES, Agilent).

For the microelements, standard solutions of $0.1,0.5,1.0,2.5,5.0$, and $10.0 \mathrm{mg} / \mathrm{L}$ were used for the construction of calibration curves of $\mathrm{Zn}, \mathrm{Fe}, \mathrm{Cu}$, and $\mathrm{Mn}$. $\mathrm{Zn}$ was detected at $213.857 \mathrm{~nm}, \mathrm{Fe}$ was detected at $259.940 \mathrm{~nm}, \mathrm{Cu}$ was detected at $327.395 \mathrm{~nm}$, and $\mathrm{Mn}$ was detected at $403.076 \mathrm{~nm}$.

On the other hand, standard solutions of $0.5,1.0,2.5,5.0$, and $10.0 \mathrm{mg} / \mathrm{L}$ were used for $\mathrm{Ca}, \mathrm{Mg}, \mathrm{K}$, and $\mathrm{Na}$. Appropriate dilutions of samples were made with ultrapure water. All standards and samples included $1 \mathrm{~g} / \mathrm{L}$ of cesium and $1 \mathrm{mg} / \mathrm{L}$ of yttrium (internal standard). Ca was detected at $393.366 \mathrm{~nm}, \mathrm{Mg}$ was detected at $285.213 \mathrm{~nm}$, Na was detected at $588.995 \mathrm{~nm}$, $\mathrm{K}$ was detected at $766.491 \mathrm{~nm}$, and $\mathrm{Y}$ at $371.029 \mathrm{~nm}$. 


\subsection{Amino acid profile analysis.}

The analysis of total amino acids was based on an in-house developed method. Briefly, $50 \mathrm{mg}$ of sample was weighted in a tube, and a hydrolysis method was performed using $4 \mathrm{M}$ methane sulfonic acid. The tube was sealed under nitrogen gas to ensure oxygen-free conditions and heated in thermoreactor (WTW CR 3200) at $148{ }^{\circ} \mathrm{C}$ for $90 \mathrm{~min}$. In the next step, the mixture was filtrated to a centrifuge tube, the volume was adjusted to $10 \mathrm{~mL}$ with water and centrifuged at $4000 \mathrm{rpm}$ for five minutes. $0.5 \mathrm{~mL}$ of supernatant was diluted with a mixture of acetonitrile: water $(50: 50, \mathrm{v} / \mathrm{v})$ to $5 \mathrm{~mL}$. Additional dilutions of this mixture were made in acetonitrile: water (50:50, v/v) and injected into the LC-MS/MS system. The analysis was performed using liquid chromatography coupled to a triple quadrupole mass spectrometer (TSQ Quantum Access, Thermo Scientific). Chromatographic separation was performed using an ACQUITY BEH amide column (150 mm x $2.1 \mathrm{~mm}, 1.7 \mu \mathrm{m}$, Waters $)$, and the mobile phase consisted of (A) acetonitrile, formic acid $0.15 \%$ and (B) $5 \mathrm{mM}$ ammonium formate, formic acid $0.15 \%$. Selected reaction monitoring (SRM) with electrospray ionization (ESI) in positive mode was applied.

\section{Results and Discussion}

\subsection{Results.}

The Nutritional and Energy Values of the mealworm and cricket flour samples analyzed are presented in Table 1. Both samples had a fairly high content in protein and fat, with cricket flour containing less fat than the sample of mealworms but more protein. Both types of insects contained similarly low ash levels, while mealworms were higher in carbohydrates and dietary fiber. The energy content of both mealworms and cricket flour was similar to the former, having a slightly higher energy value.

Table 1. Nutritional and Energy Values of the samples analyzed.

\begin{tabular}{c|c|c|c|c} 
& $\begin{array}{c}\text { Mealworms } \\
\text { (fresh) }\end{array}$ & $\begin{array}{c}\text { Mealworms } \\
\text { (dry) }\end{array}$ & Cricket flour & $\begin{array}{c}\text { Cricket flour } \\
\text { (dry) }\end{array}$ \\
\hline Humidity (g/ 100g) & 75.8 & -- & 10.0 & -- \\
\hline Ash (g/ 100g) & 1.16 & 5.24 & 4.98 & 5.53 \\
\hline Proteins (g/ 100g) & 10.2 & 57.8 & 65.3 & 72.6 \\
\hline Fat (g/ 100g) & 5.66 & 23.8 & 15.1 & 16.8 \\
\hline Dietary fiber (g/ 100g) & 1.20 & 5.33 & 1.46 & 1.62 \\
\hline Carbohydrates (g/ 100g) & 7.18 & -- & 4.62 & - \\
\hline Total Energy Value & & & & 1747 \\
KJ/100g & 505 & 2087 & 416 & 1941 \\
Kcal/100g & 120 & 496 & & 462
\end{tabular}

Table 2 shows the fatty acid composition of the samples. Comparing the two samples, we observe that very few fatty acids show similar concentrations. Such are myristoleic acid (C14: 1), palmitic acid (C16: 0), arachidic acid (C20: 0), eicosadienoic acid (C20: 2 n6), and DHA, which is not even detected in any of the two samples. An additional similarity is observed in the total content of polyunsaturated fatty acids but also the low concentration of total saturated fatty acids. The samples showed differences in their lipid profile, both in the concentrations of many fatty acids and in the presence of fatty acids in only one of the two samples. The fatty acids caprylic acid (C8: 0), lignoceric acid (C24: 0), EPA (C20: 5 n3), $\gamma$ linolenic acid (C18: $3 \mathrm{n6}$ ), dihomo- $\gamma$-linolenic acid (C20: $3 \mathrm{n} 6)$, arachidonic acid (C20: $4 \mathrm{n} 6$ ), erucic acid (C22: $1 \mathrm{n} 9)$, nervonic acid (C24: $1 \mathrm{n} 9)$ and eicosatrienoic acid (C20: $3 \mathrm{n} 3)$ were 
detected only in cricket flour, while tridecylic acid (C13: 0) only in mealworms. Also, in the sample of cricket flour, the fatty acids lauric acid (C12: 0), myristic acid (C14: 0), pentadecylic acid (C15: 0), margaric acid (C17: 0), palmitoleic acid (C16: $1 \mathrm{n} 7 \mathrm{cis}$ ), elaidic acid (C18: $1 \mathrm{n}$ 9 trans), oleic acid (C18: $1 \mathrm{n} 9$ cis), gondoic acid (C20: $1 \mathrm{n} 9)$, linoleic acid (C18: $2 \mathrm{n} 6 \mathrm{cis})$ and $\alpha-$ linolenic acid (C18: $3 \mathrm{n} 3$ ) were detected at much higher concentrations than the mealworm sample. Similarly, there were many fatty acids in the sample of mealworms in much higher concentrations than those in cricket flour. These fatty acids were stearic acid (18: 0), heneicosylic acid (C21: 0), behenic acid (C22: 0), tricosylic acid (C23: 0), linolelaidic acid (C18: $2 \mathrm{n} 6$ trans), docosadienoic acid (C22: 2), pentadecenoic acid (C15: 1), and heptadecenoic acid (C17: 1). In general, mealworms had twice the omega-3 fatty acid content and a much higher concentration of total monounsaturated fatty acids, while cricket flour had a slightly higher concentration of omega- 6 fatty acids. The downside is that no sample had the valuable DHA fatty acid and the EPA where it was detected only in crickets was quite low. Finally, total omega-3 and omega- 6 as well as the two essential fatty acids for humans (C18: $3 \mathrm{n} 3, \mathrm{C} 18: 2$ n6,) were found in both insects in low but satisfactory concentrations.

Table 2. Fatty acid content (g/100g) of the samples.

\begin{tabular}{|c|c|c|c|c|}
\hline Fatty acids & $\begin{array}{l}\text { Mealworms } \\
\text { (fresh) }\end{array}$ & $\begin{array}{l}\text { Mealworms } \\
\text { (dry) }\end{array}$ & Cricket flour & $\begin{array}{l}\text { Cricket flour } \\
\text { (dry) }\end{array}$ \\
\hline C8:0 & -- & -- & 0.0019 & 0.0021 \\
\hline C12:0 & 0.0124 & 0.0431 & 0.0083 & 0.0092 \\
\hline C13:0 & 0.0028 & 0.0105 & -- & -- \\
\hline C14:0 & 0.157 & 0.583 & 0.0679 & 0.0754 \\
\hline C14:1 & 0.0220 & 0.0377 & 0.0379 & 0.0421 \\
\hline C15:0 & 0.0118 & 0.0457 & 0.0115 & 0.0128 \\
\hline C15:1 & 0.0021 & 0.0033 & 0.0054 & 0.006 \\
\hline C16:0 & 1.06 & 4.01 & 2.77 & 3.08 \\
\hline C16:1n7cis & 0.0815 & 0.312 & 0.0895 & 0.0994 \\
\hline C17:0 & 0.0118 & 0.0527 & 0.0287 & 0.0319 \\
\hline C17:1 & -- & 0.0120 & 0.0235 & 0.0261 \\
\hline C18:0 & 0.171 & 0.767 & 0.934 & 1.038 \\
\hline C18:1n9 trans & 0.0104 & 0.0534 & 0.0147 & 0.0163 \\
\hline C18:1n9 cis & 2.30 & 9.12 & 2.11 & 2.34 \\
\hline C18:2n6 trans & -- & 0.0045 & 0.0216 & 0.024 \\
\hline C18:2n6 cis & 1.93 & 7.91 & 4.12 & 4.58 \\
\hline C18:3n6 & -- & -- & 4,09 & 4,54 \\
\hline C18:3n3 & 0.101 & 0.371 & 0.111 & 0.123 \\
\hline C20:0 & 0.0063 & 0.0461 & 0.0651 & 0.0723 \\
\hline Fatty acids & $\begin{array}{l}\text { Mealworms } \\
\text { (fresh) }\end{array}$ & $\begin{array}{l}\text { Mealworms } \\
\text { (dry) }\end{array}$ & Cricket flour & $\begin{array}{l}\text { Cricket flour } \\
\text { (dry) }\end{array}$ \\
\hline C20:1n9 & 0.0093 & 0.0373 & 0.0059 & 0.0066 \\
\hline C20:2n6 & 0.0035 & 0.0161 & 0.0162 & 0.0180 \\
\hline C21:0 & 0.0014 & 0.0072 & 0.0276 & 0.0307 \\
\hline C20:3n6 & -- & -- & 0.0130 & 0.0144 \\
\hline C20:4n6 & -- & -- & 0.0306 & 0.0340 \\
\hline C20:3n3 & -- & -- & 0.0749 & 0.0832 \\
\hline C22:0 & 0.0022 & 0.0247 & 0.0461 & 0.0512 \\
\hline C20:5n3 EPA & -- & -- & 0.0031 & 0.0034 \\
\hline C22:1n9 & -- & -- & 0.0251 & 0.0279 \\
\hline C22:2 & -- & 0.0068 & 0.0100 & 0.0111 \\
\hline C23:0 & -- & 0.0117 & 0.0207 & 0.0230 \\
\hline C24:0 & -- & -- & 0.0078 & 0.0087 \\
\hline C24:1n9 & -- & -- & 0.0077 & 0.0086 \\
\hline C22:6n3 DHA & -- & -- & -- & -- \\
\hline $\begin{array}{c}\text { Total Omega-3 Fatty } \\
\text { Acids }\end{array}$ & 0.10 & 0.37 & 0.19 & 0.21 \\
\hline $\begin{array}{c}\text { Total Omega-6 Fatty } \\
\text { Acids }\end{array}$ & 1.94 & 7.94 & 8.30 & 9.22 \\
\hline Saturated Fatty Acids & 1.44 & 5.61 & 3.98 & 4.42 \\
\hline
\end{tabular}




\begin{tabular}{c|c|c|c|c} 
Fatty acids & $\begin{array}{c}\text { Mealworms } \\
\text { (fresh) }\end{array}$ & $\begin{array}{c}\text { Mealworms } \\
(\mathbf{d r y})\end{array}$ & Cricket flour & $\begin{array}{c}\text { Cricket flour } \\
\text { (dry) }\end{array}$ \\
\hline $\begin{array}{c}\text { Monounsaturated fatty } \\
\text { acids }\end{array}$ & 2.43 & 9.58 & 2.32 & 2.58 \\
\hline $\begin{array}{c}\text { Polyunsaturated Fatty } \\
\text { Acids }\end{array}$ & 2.04 & 8.31 & 8.49 & 9.43 \\
\hline EPA+DHA & -- & -- & 0.0031 & 0.0034
\end{tabular}

The analyzes for minerals are presented in Table 3. Both macroelements $(\mathrm{Ca}, \mathrm{P}, \mathrm{Mg}$, $\mathrm{Na}, \mathrm{K})$ and trace elements ( $\mathrm{Zn}, \mathrm{Fe}, \mathrm{Cu}, \mathrm{Mn}$ ) were identified in the samples tested. According to the results, high concentrations of $\mathrm{Mg}, \mathrm{P}, \mathrm{Zn}$, and $\mathrm{Cu}$ were found in both samples from the insects, where they can meet the daily needs of average adults. In contrast to $\mathrm{Ca}, \mathrm{Na}, \mathrm{K}$, and $\mathrm{Fe}$, the concentrations were low for both insects, so they could not meet the daily needs of average adults with normal consumption. The Mn content was high in the cricket flour sample, while it was much lower and insufficient in the mealworms sample. Finally, comparing the results for each macronutrient - trace element in the insect samples, there were no major differences for $\mathrm{P}, \mathrm{K}, \mathrm{Cu}$, and $\mathrm{Fe}$.

Table 3. Concentration of minerals in $\mathrm{mg}$ per $\mathrm{kg}$ of sample.

\begin{tabular}{c|c|c|c|c} 
Minerals & $\begin{array}{c}\text { Mealworms } \\
\text { (fresh) }\end{array}$ & $\begin{array}{c}\text { Mealworms } \\
\text { (dry) }\end{array}$ & Cricket flour & $\begin{array}{c}\text { Cricket flour } \\
\text { (dry) }\end{array}$ \\
\hline Magnesium (Mg) & 694 & 3041 & 1141 & 1268 \\
\hline Phosphorus (P) & 2835 & 10339 & 8900 & 9889 \\
\hline Calcium (Ca) & 344 & 539 & 755 & 838.9 \\
\hline Sodium (Na) & 670 & 2677 & 5287 & 5874 \\
\hline Potassium (K) & 3462 & 16710 & 14996 & 16662 \\
\hline Zinc (Zn) & 39.6 & 126 & 252 & 280 \\
\hline Iron (Fe) & 13.7 & 48.2 & 59.9 & 66.6 \\
\hline Copper (Cu) & 5.0 & 20.9 & 25.3 & 28.1 \\
\hline Manganese (Mn) & 2.0 & 9.4 & 44.6 & 49.6
\end{tabular}

Table 4. Amino acid content (g/100g) of the samples.

\begin{tabular}{c|c|c|c} 
AMINO ACIDS & Cricket flour & Cricket flour (dry) & Mealworms (dry) \\
\hline Alanine & 5.28 & 5.87 & 4.06 \\
\hline Arginine & 4.50 & 5.00 & 2.69 \\
\hline Aspartic acid & 5.26 & 5.84 & 4.67 \\
\hline Valini & 3.65 & 4.06 & 3.33 \\
\hline Glutamic acid & 7.44 & 8.27 & 6.66 \\
\hline Glycine & 3.30 & 3.67 & 3.22 \\
\hline Threonine & 2.55 & 2.83 & 2.34 \\
\hline Isoleucine & 3.27 & 3.63 & 2.44 \\
\hline Leucine & 7.48 & 8.31 & 6.20 \\
\hline Histidine & 1.78 & 1.98 & 2.05 \\
\hline Cysteine & 0.63 & 0.70 & 0.41 \\
\hline Lysine & 3.60 & 4.00 & 3.60 \\
\hline Methionine & 1.08 & 1.20 & 0.51 \\
\hline Proline & 3.83 & 4.26 & 4.04 \\
\hline Serine & 3.16 & 3.51 & 2.81 \\
\hline Tryptophan & 0.41 & 0.46 & 0.47 \\
\hline Tyrosine & 3.50 & 3.89 & 4.98
\end{tabular}

While for the rest, the difference in their content is remarkable. As for $\mathrm{Ca}, \mathrm{Na}, \mathrm{Zn}$, and $\mathrm{Mn}$, the concentration was much higher in cricket flour, while for $\mathrm{Mg}$, it was higher in the sample of mealworms. The amino acid analyzes are shown in Table 4. These insects appear to be a very good source of most amino acids, as they contain all the essential amino acids for humans in high concentrations. According to the results, both samples analyzed met the amino acid requirements for both infants and children as well as adults. The concentrations of all the 
essential and non-essential amino acids identified were very high and far exceeded the average needs of the human body. By comparison, both mealworms and cricket flour had similar total amino acid concentrations, with slightly higher crickets. Individually for most amino acids, the concentrations in both samples were very close, except for somewhere the cricket sample was up to twice the values of the mealworms sample. These amino acids were alanine, arginine, leucine, methionine, cysteine, and phenylalanine.

\subsection{Discussion.}

The results of the analyzes in Table 1 for both cricket flour and mealworms are similar to previous studies in these insect species, but some differences may be due to many factors such as raw material, diet, the morphological characteristics of the insects, and the different method of analysis [81-98].

According to other studies, the protein content of T. molitor larvae appears to be on average $52.4 \%$ and ranges from $47.0 \%$ to $60.2 \%$ [81-93]. Crude protein values for T. molitor larvae or larvae flour were analyzed in previous studies with the Dumas combustion method [85], the Randall method [87, 88], the Kjeldahl method [82-84, 86, 89, 90], and by the elemental method of analysis [90]. The results of research using the Kjeldahl method for the determination of proteins were very close to ours, while the results using other analysis methods ranged mainly at lower values than ours. Depending on the processing method, the crude fat content of T. molitor larvae appears to be on average $30.8 \%$ and ranges from $19.1 \%$ to $36.7 \%$ [81-93]. However, the average ash content is $4.2 \%$ for $T$. molitor larvae and ranges from $2.65 \%$ to $6.99 \%$ [81-93]. The mealworms analyzed in this study are lower in fat and protein than reported in some other studies, which may be due to their smaller size, higher moisture, diet, and other factors that have already been reported [97, 98]. As the content of lipids and other nutrients and micronutrients changes with increasing size and age in the worm's larvae, as well as with the diet of the insects [98]. Although both acidic dietary fiber (ADF) and neutral dietary fiber (NDF) have been previously reported for these species, the present study is one of the few to report total dietary fiber for commercial feeding insects. The amount of fiber contained in insects can consist of crude fiber, acid detergent fiber, and neutral detergent fiber. The fiber content of T. molitor larvae comes from their skins. The crude fiber content of T. molitor larvae is on average $7.43 \%$ and ranges from $4.19 \%$ to $22.35 \%$ [81, 84-89, 91].

According to data from other studies on different types of crickets and crickets flour, we see that the percentages in the contents of various nutrients are differentiated by factors such as the type of insect, age, diet, and method of analysis [86, 90, 94-96]. Crude protein ranges from $42.0 \%$ to $76.19 \%$, fat from $8.9 \%$ to $43.9 \%$, crude fiber from $2.9 \%$ to $10.37 \%$, ash from $2.9 \%$ to $9.69 \%$ and carbohydrates from $5.1 \%$ to $21.8 \%$ [86, 90, 94-96]. All values reported for both insect species correspond to dry samples.

The calcium content of the samples analyzed is higher than other reports [97-99]. The results for phosphorus were much higher than for calcium in the samples and are similar to those reported in other studies on these insects [97, 98]. The magnesium, sodium, and potassium content is similar to the results of other studies in these insect species, although the value of sodium in worms is high $[97,98]$. The iron, copper, zinc, and manganese levels were variable, but all values were similar and showed small deviations from those reported for these insect species [97, 98]. In addition, although the insects analyzed in this report were fasted before being analyzed, the synthesis of minerals, in general, is probably a function of the 
insect's food sources, both the minerals absorbed from the diet and those that remain in the gastrointestinal tract $[100,101]$. According to researches for T. molitor larvae calcium values range from $0.04 \%$ to $0.50 \%$, phosphorus values from $0.70 \%$ to $1.04 \%$, sodium values from $0.21 \%$ to $0.36 \%$, and potassium prices range from $0.85 \%$ to $1.12 \%$. Also, the prices of iron for T. molitor larvae range from 63.0 to $100.0 \mathrm{mg} / \mathrm{kg}$, zinc from 102.0 to $117.4 \mathrm{mg} / \mathrm{kg}$ and copper from 12.3 to $20.0 \mathrm{mg} / \mathrm{kg}$ [86, 87, 88, 90]. Regarding the results of recent studies on minerals in various types of crickets and crickets flour, we see that the ranges of values in $\mathrm{mg} / 100 \mathrm{~g}$ for each are the following, Ca 99.6 - 240.2, P 543.4 - 1169.6, Mg 86.0 - 152.7, Na 255.3 471.4, K 644.4 - 1224.0, Zn 13.3 - 22.4, Fe 3.3 - 10.6, Cu 2.2 - 4.6, and Mn 4.1 - 12.5 [86, 94, 96].

In addition, the amino acid profile reported in the present study is consistent and slightly different, both from the amino acid profiles previously reported for these species and from the concentration of each amino acid identified separately [97, 98, 102, 103]. The same goes for the results of essential amino acids for the human body. T. molitor larvae have high quality and quantity of proteins and amino acid profiles. Therefore, they are considered a highly viable alternative source of protein. Leu, Val, and Lys are the most abundant essential amino acids in T. molitor larvae, while His, Met and Trp are the least abundant. The average percentage content for each amino acid, according to other studies, is very close to the results of this study, with differences mainly in the amino acids Leu, Met, and Cys [82-84, 86-89, 92, 104, 105]. Arg, His, Iso, Leu, Lys, Met, Phe, Thr, Val, and Trp have an average concentration of 2.99, 1.91, 3.01, 4.17, 3.18, 1.06, 2.03, 2.22, 3.39, and 0.71, respectively. While Ala, Asp, Cys, Gly, Glu, Pro, Ser, and Tyr have 4.46, 4.20, 1.23, 2.92, 6.70, 3.42, 2.71, and 3.98, respectively [82$84,86-89,92,104,105]$. For cricket flour, the amino acid values of the present work were considerably higher than the results of a study conducted on two different types of crickets on dry samples, while for Cys, they were much lower [86].

Finally, the fatty acid profile observed for these insects differs in several respects from other studies [86-88, 98, 104, 105]. As the fatty acid content of insects and other animals such as poultry and pigs can be altered by food, as reported in many studies [49]. In general, mealworms had twice as much omega-3 fatty acids and a much higher concentration of total monounsaturated fatty acids, while cricket flour had a slightly higher concentration of omega6 fatty acids. The downside is that no sample contained the valuable DHA fatty acid and the EPA detected only in crickets was quite low in concentration. Usually, DHA and EPA are not found in terrestrial insects but constitute a significant proportion of total fatty acids in aquatic insects [106-108]. It has been suggested that long-chain omega-3 fatty acids can be transported from aquatic to terrestrial ecosystems [107]. Finally, total omega-3 and omega-6, as well as the two essential fatty acids for humans (C18:3n3, C18:2n6), were found in both insects in satisfactory concentrations. The samples of this study contained a higher proportion of linolenic acid (LNA - 18: 3 n-3) than reported in other studies [97]. On the positive side, the samples analyzed had higher concentrations of polyunsaturated, monounsaturated fatty acids, which are necessary to prevent many cardiovascular diseases, and low levels of saturated fatty acids. Regarding the results for the fatty acids of $T$. molitor larvae of other studies, it appears that myristic acid (C14: 0) ranges from 2.12\% to 5.21\%, palmitic acid (C16: 0) ranges from 9, 33\% to $17.21 \%$ and stearic acid (C18: 0$)$ ranges from $0.26 \%$ to $3.06 \%$. Palmitoleic acid (C16: 1$)$ ranges from $9.33 \%$ to $17.24 \%$, oleic acid (C18: $1 \mathrm{n} 9)$ ranges from $40.78 \%$ to $49.71 \%$, linoleic acid (C18: $2 \mathrm{n} 6)$ ranges from $24.19 \%$ to $35.58 \%$, linolenic acid (C18: $3 \mathrm{n} 3)$ ranges from $0.35 \%$ to $2.27 \%, \gamma$-linoleic acid (C18: $3 \mathrm{n} 6)$ ranges from $0.03 \%$ to $1.85 \%$ and eicosenoic acid (C20: 
1n9) ranges from $0.06 \%$ to $0.39 \%$, where we observe in many places large differences that may be due to various reasons that have been reported [86-88, 104, 105]. However, for cricket flour, the results for fatty acids were similar to those of a recent study in two cricket species and differed little in terms of both quality and quantity [86].

\section{Conclusions}

In conclusion, in most cases, insects are an easily accessible source of protein, lipids, carbohydrates, dietary fiber, certain vitamins, and minerals. Insects are sources of polyunsaturated and monounsaturated fatty acids, which are essential for preventing many cardiovascular diseases. Many studies have also shown that most insects have a well-balanced nutrient profile and meet amino acid requirements for humans. Most edible insects provide satisfactory levels of essential amino acids. These are also confirmed by the present research for the samples analyzed. Insects are rich in many micronutrients such as magnesium, copper, iron, and zinc. A study on the nutritional composition of Tenormio molitor (larvae), adult crickets (Gryllodes sigillatus), and adult locusts (Schistocerca gregaria) showed that they contained 40, 130, and $70 \mathrm{mg}$ of calcium per $100 \mathrm{~g}$ of dry weight, respectively. In this study, calcium values for both samples of insects were very close to the above, while beef has an average of 4-27 mg, pork 5-28, and poultry only 5-14 mg / $100 \mathrm{~g}$ [109]. The same goes for the iron content. According to the research results, the values for iron in mealworm and cricket flour were 4.82 and $6.66 \mathrm{mg}$ per $100 \mathrm{~g}$ of dry weight, respectively. Edible insects such as the African palm weevils (Rhynchophorus phoenicis) or mopane worm (Imbrasia belina) can provide 12 and $31 \mathrm{mg}$ of iron per $100 \mathrm{~g}$ of body weight. On the other hand, chicken and beef provide only 1.2 and $3 \mathrm{mg}$ of iron per $100 \mathrm{~g}$ of body weight, respectively [12]. Several species of aquatic hemiptera and larvae of the yellow mealworm beetle also have significantly high iron content [24]. Zinc is a very important metal for growth and can be found in most insects, such as the larvae of African palm weevil (Rhynchophorus phoenicis), which contain $26.5 \mathrm{mg}$ per $100 \mathrm{~g}$ [12]. While in the insect species examined, it was $12.6 \mathrm{mg} / 100 \mathrm{~g}$ dry weight for mealworms and $28.0 \mathrm{mg} / 100 \mathrm{~g}$ dry weight for crickets. High potassium and sodium content have been recorded from the cricket larvae, calcium, phosphorus, and manganese from adult crickets (Acheta domesticus), and copper from the cavorting emperor moth (Usta terpsichore) [24]. Finally, the inorganic composition depends significantly on the diet of the insects [98]. For example, calcium levels in wax worms (caterpillars of wax moths), Tenebrio molitor beetle larvae, pupae of the silkworm (Bombyx mori), and house crickets increased 5 to 20 times when high-feeding insects in calcium [26]. Commercial insect production is usually followed by a low-cost diet designed to maximize insect growth and reproduction without considering nutrient content [98]. Study data clearly show that the insect's nutrient content can change substantially by changing the insect's diet during development [98]. Although not all nutrients (e.g., calcium) can be easily changed, in many cases, the nutritional content of insects fed fortified diets closely mimics that of wild insects [98]. Therefore, commercial feeding insects intended for human food or animal feed must be reared under special conditions and with specific diets depending on the species, both to preserve their nutrients and improve and substantially enhance their nutritional value. 


\section{Funding}

This research is financially supported by the Special Research Account of National and Kapodistrian University of Athens No. 13992.

\section{Acknowledgments}

The authors would like to thank the Special Research Account of the National and Kapodistrian University of Athens.

\section{Conflicts of Interest}

The authors declare no conflict of interest.

\section{References}

1. van Huis, A. Did early humans consume insects. Journal of Insects as Food and Feed 2017, 3, 161-163, http://dx.doi.org/10.3920/JIFF2017.x006.

2. Ortiz, J.C. et al. Insect mass production technologies. Insects as sustainable food ingredients. Academic Press 2016, 153-201, https://doi.org/10.1016/B978-0-12-802856-8.00006-5.

3. Hardy, K. et al. Diet and environment 1.2 million years ago revealed through analysis of dental calculus from Europe's oldest hominin at Sima del Elefante, Spain. The Science of Nature 2017, 104, 2, https://doi.org/10.1007/s00114-016-1420-x.

4. McDonough, K.N. Middle Holocene menus: dietary reconstruction from coprolites at the Connley Caves, Oregon, USA. Archaeological and Anthropological Sciences 2019, 11, 5963-5982, https://doi.org/10.1007/s12520-01900828-1.

5. Feng, Y.; Zhao, M.; Ding, W.F.; Chen, X.M. Overview of edible insect resources and common species utilisation in China. Journal of Insects as Food and Feed 2020, 6, 13-25, https://doi.org/10.3920/JIFF2019.0022.

6. Van Huis, A. et al. Edible insects: future prospects for food and feed security. Food and Agriculture Organization of the United Nations 2013, FAO Forestry Paper 171.

7. Raheem, D. et al. Traditional consumption of and rearing edible insects in Africa, Asia and Europe. Critical Reviews in Food Science and Nutrition 2019, 59, 2169-2188, https://doi.org/10.1080/10408398.2018.1440191.

8. Batat, W.; Peter, P. The healthy and sustainable bugs appetite: factors affecting entomophagy acceptance and adoption in Western food cultures. Journal of Consumer Marketing 2020, 37, 291303, https://doi.org/10.1108/JCM-10-2018-2906.

9. Akhtar, Y.; Isman, M. B. Insects as an alternative protein source. Proteins in food processing (second edition) 2018, Woodhead Publishing Series in Food Science, Technology and Nutrition, 263-288, https://doi.org/10.1016/B978-0-08-100722-8.00011-5.

10. Shin, J.T.; Baker, M.A.; Kim, Y.W. Edible insects uses in south Korean gastronomy: "Korean edible insect laboratory" case study. Edible insects in sustainable food systems 2018, Springer, Cham, 147-159, https://doi.org/10.1007/978-3-319-74011-9_10.

11. Defoliart, G.R. Insects as food: why the western attitude is important. Annual review of entomology 1999, 44, 2150, https://doi.org/10.1146/annurev.ento.44.1.21.

12. Tao, J.; Li, Y.O. Edible insects as a means to address global malnutrition and food insecurity issues. Food Quality and Safety 2018, 2, 17-26, https://doi.org/10.1093/fqsafe/fyy001.

13. Kearney, J. Food consumption trends and drivers. Philosophical Transactions of the Royal Society B: Biological Sciences 2010, 365, 2793-2807, https://doi.org/10.1098/rstb.2010.0149.

14. Food and Agriculture Organization. FAO statistical yearbook 2012. Food and agriculture organization of the United Nations Rome 2012, http://www.fao.org/3/i2490e/i2490e00.htm.

15. Herrero, M. et al. Greenhouse gas mitigation potentials in the livestock sector. Nature Climate Change 2016, 6 , 452-461, https://doi.org/10.1038/nclimate2925.

16. Govorushko, S. Human impact on the environment: an illustrated world atlas. Springer Cham Heidelberg New York Dordrecht London 2016, pp. 360, https://doi.org/10.1007/978-3-319-24957-5.

17. Cadinu, L.A. et al. Insect rearing: Potential, challenges, and circularity. Sustainability 2020, 12, 4567, https://doi.org/10.3390/su12114567. 
18. Chakravorty, J. et al. Nutritional and anti-nutritional composition of Oecophylla smaragdina (Hymenoptera: Formicidae) and Odontotermes sp. (Isoptera: Termitidae): Two preferred edible insects of Arunachal Pradesh, India. Journal of Asia-Pacific Entomology 2016, 19, 711-720, https://doi.org/10.1016/j.aspen.2016.07.001.

19. Sun-Waterhouse, D. et al. Transforming insect biomass into consumer wellness foods: A review. Food Research International 2016, 89, 129-151, https://doi.org/10.1016/j.foodres.2016.10.001.

20. Stull, V.J. et al. Crude protein, amino acid, and iron content of Tenebrio molitor (Coleoptera, Tenebrionidae) reared on an agricultural byproduct from maize production: An exploratory study. Annals of the Entomological Society of America 2019, 112, 533-543, https://doi.org/10.1093/aesa/saz024.

21. Kwiri, R.; Mujuru, F.M.; Gwala, W. Nutrient Composition and Bioactive Components of Mopane Worm (Gonimbrasia belina). African Edible Insects As Alternative Source of Food, Oil, Protein and Bioactive Components 2020, Springer, Cham, 241-256, https://doi.org/10.1007/978-3-030-32952-5_17.

22. Oonincx, D.G.A.B.; De Boer, I.M.J. Environmental impact of the production of mealworms as a protein source for humans - a life cycle assessment. PloS one 2012, 7, e51145, https://doi.org/10.1371/journal.pone.0051145.

23. Halloran A. et al. Life cycle assessment of cricket farming in north-eastern Thailand. Journal of Cleaner Production 2017, 156, 83-94, https://doi.org/10.1016/j.jclepro.2017.04.017.

24. Nadeau, L. et al. The potential for entomophagy to address undernutrition. Ecology of food and nutrition 2015, 54, 200-208, https://doi.org/10.1080/03670244.2014.930032.

25. Govorushko, S. Global status of insects as food and feed source: A review. Trends in Food Science \& Technology 2019, 91, 436-445, https://doi.org/10.1016/j.tifs.2019.07.032.

26. Mlček J. et al. A comprehensive look at the possibilities of edible insects as food in Europe-A Review. Polish Journal of Food and Nutrition Sciences 2014, 64, 147-157, https://doi.org/10.2478/v10222-012-0099-8.

27. Pimentel D.; Pimentel, M. Sustainability of meat-based and plant-based diets and the environment. The American journal of clinical nutrition 2003, 78, 660S-663S, https://doi.org/10.1093/ajcn/78.3.660S

28. Collavo, A. et al. House cricket small-scale farming. Ecological implications of minilivestock: potential of insects, rodents, frogs and snails 2005, CRC Press, Boca Raton, 519-544.

29. Cerritos, R. Grasshoppers in agrosystems: pest or food ? CAB Reviews: Perspectives in Agriculture, Veterinary Science, Nutrition and Natural Resources 2011, 6, 1-9, http://dx.doi.org/10.1079/PAVSNNR20116017.

30. van Huis, A. Insects as Human Food. Ethnozoology Animals in our Lives 2018, Elsevier Inc. Academic Press, 195-213, https://doi.org/10.1016/B978-0-12-809913-1.00011-9.

31. Yen A.L. Insects as food and feed in the Asia Pacific region: current perspectives and future directions. Journal of Insects as Food and Feed 2015, 1, 33-55, https://doi.org/10.3920/JIFF2014.0017.

32. Ramos-Elorduy, J. Anthropo-entomophagy: Cultures, evolution and sustainability. Entomological Research 2009 , 39, 271-288, https://doi.org/10.1111/j.1748-5967.2009.00238.x.

33. Cerritos, R. et al. Insects as food: an ecological, social and economical approach. CAB Reviews: Perspectives in Agriculture, Veterinary Science, Nutrition and Natural Resources 2009, 4, 1-10, https://doi.org/10.1079/PAVSNNR200940277.

34. Jongema, Y. List of edible insect species of the world. Wageningen University \& Research 2017, Wageningen, The Netherlands.

35. House J. Consumer acceptance of insect-based foods in the Netherlands: Academic and commercial implications. Appetite 2016, 107, 47-58, https://doi.org/10.1016/j.appet.2016.07.023.

36. Megido, R.C.; Haubruge, E.; Francis, F. Insects, the next european foodie craze ? Edible insects in sustainable food systems 2018, Springer, Cham, 353-361, https://doi.org/10.1007/978-3-319-74011-9_21.

37. Gullan, P.J.; Cranston, P.S. The insects: an outline of entomology (5 $5^{\text {th }}$ Edition) 2014, Wiley-Blackwell, pp 632.

38. Mitsuhashi, J. Edible insects of the world ( $1^{\text {st }}$ Edition) 2016, CRC Press, Boca Raton, pp 296, https://doi.org/10.1201/9781315367927.

39. Paoletti, M.G. (ed.) Ecological Implications of Minilivestock: Potential of Insects, Rodents, Frogs and Sails ( $1^{\text {st }}$ Edition) 2005, CRC Press, Boca Raton, pp 662, https://doi.org/10.1201/9781482294439.

40. van Huis, A.; Oonincx, D.G.A.B. The environmental sustainability of insects as food and feed. A review. Agronomy for Sustainable Development 2017, 37, 43, https://doi.org/10.1007/s13593-017-0452-8.

41. Preteseille, N. et al. Insects in Thailand: national leadership and regional development, from standards to regulations through association. Edible insects in sustainable food systems 2018, Springer, Cham, 435-442, https://doi.org/10.1007/978-3-319-74011-9_27.

42. Derrien, C.; Boccuni, A. Current status of the insect producing industry in Europe. Edible insects in sustainable food systems 2018, Springer, Cham, 471-479, https://doi.org/10.1007/978-3-319-74011-9_30. 
43. Hanboonsong, Y.; Jamjanya, T.; Durst, P.B. Six-legged livestock: edible insect farming, collection and marketing in Thailand. RAP Publication 2013, 3.

44. Dossey, A.T.; Tatum, J.T.; McGill, W.L. Modern insect-based food industry: current status, insect processing technology, and recommendations moving forward. Insects as sustainable food ingredients. Academic Press 2016, 113-152, https://doi.org/10.1016/B978-0-12-802856-8.00005-3.

45. Verbeke, W.; Sans, P.; Van Loo, E.J. Challenges and prospects for consumer acceptance of cultured meat. Journal of Integrative Agriculture 2015, 14, 285-294, https://doi.org/10.1016/S2095-3119(14)60884-4.

46. Makkar, H.P. et al. State-of-the-art on use of insects as animal feed. Animal Feed Science and Technology 2014, 197, 1-33, https://doi.org/10.1016/j.anifeedsci.2014.07.008.

47. Koutsos, L.; Mccomb, A.; Finke, M. Insect composition and uses in animal feeding applications: a brief review. Annals of the Entomological Society of America 2019, 112, 544-551, https://doi.org/10.1093/aesa/saz033.

48. Ido, A. et al. Dietary effects of housefly (Musca domestica) (Diptera: Muscidae) pupae on the growth performance and the resistance against bacterial pathogen in red sea bream (Pagrus major) (Perciformes: Sparidae). Applied Entomology and Zoology 2015, 50, 213-221, https://doi.org/10.1007/s13355-015-0325-z.

49. Li, Y. et al. Total replacement of fish meal with black soldier fly (Hermetia illucens) larvae meal does not compromise the gut health of Atlantic salmon (Salmo salar). Aquaculture 2020, 520, 734967, https://doi.org/10.1016/j.aquaculture.2020.734967.

50. Bosch, G. et al. Protein quality of insects as potential ingredients for dog and cat foods. Journal of nutritional science 2014, 3, e29, https://doi.org/10.1017/jns.2014.23.

51. Plantinga, E.A.; Bosch, G.; Hendriks, W.H. Estimation of the dietary nutrient profile of free-roaming feral cats: possible implications for nutrition of domestic cats. British Journal of Nutrition 2011, 106, S35-S48, https://doi.org/10.1017/S0007114511002285.

52. Vidotto-Magnoni, A.P.; Carvalho, E.D. Aquatic insects as the main food resource of fish the community in a Neotropical reservoir. Neotropical Ichthyology 2009, 7, 701-708, https://doi.org/10.1590/S167962252009000400020 .

53. Oonincx, D.G.A.B. et al. Feed conversion, survival and development, and composition of four insect species on diets composed of food by-products. PloS one 2015, 14, e0144601, https://doi.org/10.1371/journal.pone.0144601.

54. van Huis, A. Edible insects contributing to food security? Agriculture \& Food Security 2015, 4, 20, https://doi.org/10.1186/s40066-015-0041-5.

55. Tiu, L.G. Enhancing sustainability of freshwater prawn production in Ohio. Ohio State University South Centers Newsletter, Fall 2012, 11, 4, https://southcenters.osu.edu/sites/southc/files/site-library/sitedocuments/connections/fall-edition-2012.pdf.

56. Hwangbo, J. et al. Utilization of house fly-maggots, a feed supplement in the production of broiler chickens. Journal of Environmental Biology 2009, 30, 609-614.

57. van Der Fels, H.J. Risk profile related to production and consumption of insects as food and feed: EFSA Scientific Committee. EFSA journal 2015, 13, 4257, https://doi.org/10.2903/j.efsa.2015.4257.

58. Lock, E.J.; Biancarosa, I.; Gasco, L. Insects as raw materials in compound feed for aquaculture. Edible insects in sustainable food systems 2018, Springer, Cham, 263-276, https://doi.org/10.1007/978-3-319-74011-9_16.

59. Obopile, M.; Seeletso, T.G. Eat or not eat: an analysis of the status of entomophagy in Botswana. Food security 2013, 5, 817-824, https://doi.org/10.1007/s12571-013-0310-8.

60. Rumpold, B.A.; Schlüter, O. Insect-based protein sources and their potential for human consumption: Nutritional composition and processing. Animal Frontiers 2015, 5, 20-24.

61. Morris, B. Insects as food among hunter-gatherers. Anthropology Today 2008, 24, 6-8, https://doi.org/10.1111/j.1467-8322.2008.00558.x.

62. Baker, M.A.; Legendre, T.S.; Kim, Y.W. Edible insect gastronomy. The Routledge Handbook of Gastronomic Tourism 2019, Routledge, Taylor \& Francis Group, 422-429, https://doi.org/10.4324/9781315147628.

63. Menzel, P.; D'Aluisio, F. Man eating bugs: The art and science of eating insects. Ten Speed Press 1998, Berkeley, Calif.

64. Gordon, D.G. The Eat-A-Bug Cookbook, Revised: 40 Ways to Cook Crickets, Grasshoppers, Ants, Water Bugs, Spiders, Centipedes, and Their Kin. Ten Speed Press 2013.

65. van Huis, A.; van Gurp, H.; Dicke, M. The insect cookbook: food for a sustainable planet. Columbia University Press 2014, https://doi.org/10.7312/vanh16684.

66. van Huis, A. Potential of insects as food and feed in assuring food security. Annual review of entomology 2013, 58, 563-583, https://doi.org/10.1146/annurev-ento-120811-153704. 
67. Han, R. et al. An overview of the South Korean edible insect food industry: Challenges and future pricing/promotion strategies. Entomological Research 2017, 47, 141-151, https://doi.org/10.1111/17485967.122300.

68. Gahukar, R.T. Insects as human food: are they really tasty and nutritious? Journal of Agricultural \& Food Information 2013, 14, 264-271, https://doi.org/10.1080/10496505.2013.803418.

69. Belluco, S. et al. Edible insects in a food safety and nutritional perspective: a critical review. Comprehensive reviews in food science and food safety 2013, 12, 296-313, https://doi.org/10.1111/1541-4337.12014.

70. Belluco, S.; Halloran, A.; Ricci, A. New protein sources and food legislation: the case of edible insects and EU law. Food Security 2017, 9, 803-814, https://doi.org/10.1007/s12571-017-0704-0.

71. Testa, M., et al. Ugly but tasty: A systematic review of possible human and animal health risks related to entomophagy. Critical reviews in food science and nutrition 2017, 57, 3747-3759, https://doi.org/10.1080/10408398.2016.1162766.

72. Poma, G. et al. Evaluation of hazardous chemicals in edible insects and insect-based food intended for human consumption. Food and Chemical Toxicology 2017, 100, 70-79, https://doi.org/10.1016/j.fct.2016.12.006.

73. Grabowski, N.T.; Klein, G. Bacteria encountered in raw insect, spider, scorpion, and centipede taxa including edible species, and their significance from the food hygiene point of view. Trends in Food Science \& Technology 2017, 63, 80-90, https://doi.org/10.1016/j.tifs.2017.01.007.

74. Mézes, M.; Erdélyi, M. Food safety of edible insects. African edible insects as alternative source of food, oil, protein and bioactive components 2020, Springer, Cham, 83-94, https://doi.org/10.1007/978-3-030-32952-5_5.

75. Chomchai, S.; Chomchai, C. Histamine poisoning from insect consumption: an outbreak investigation from Thailand. Clinical Toxicology 2018, 56, 126-131, https://doi.org/10.1080/15563650.2017.1349320.

76. Van Broekhoven, S. et al. Degradation and excretion of the Fusarium toxin deoxynivalenol by an edible insect, the Yellow mealworm (Tenebrio molitor L.). World Mycotoxin Journal 2017, 10, 163-169, https://doi.org/10.3920/WMJ2016.2102.

77. Garino, C. et al. Quantitative allergenicity risk assessment of food products containing yellow mealworm (Tenebrio molitor). Food and Chemical Toxicology 2020, 142, 111460 , https://doi.org/10.1016/j.fct.2020.111460.

78. Ribeiro, J.C. et al. Allergic risks of consuming edible insects: A systematic review. Molecular nutrition \& food research 2018, 62, 1700030, https://doi.org/10.1002/mnfr.201700030.

79. Feng, Y. et al. Edible insects in China: Utilization and prospects. Insect Science 2018, 25, 184-198, https://doi.org/10.1111/1744-7917.12449.

80. Sokol, W.N. Grasshopper sensitization in patients allergic to crustaceans, mites, and cockroaches: Should grasshopper-containing products carry a warning ? Annals of Allergy, Asthma \& Immunology 2020, 124, 518-520, https://doi.org/10.1016/j.anai.2020.02.011.

81. Ramos-Elorduy, J. et al. Use of Tenebrio molitor (Coleoptera: Tenebrionidae) to recycle organic wastes and as feed for broiler chickens. Journal of economic entomology 2002, 95, 214-220, https://doi.org/10.1603/0022-049395.1.214.

82. De Marco, M. et al. Nutritional value of two insect larval meals (Tenebrio molitor and Hermetia illucens) for broiler chickens: apparent nutrient digestibility, apparent ileal amino acid digestibility and apparent metabolizable energy. Animal Feed Science and Technology 2015, 209, 211-218, https://doi.org/10.1016/j.anifeedsci.2015.08.006.

83. Bovera, F. et al. Use of Tenebrio molitor larvae meal as protein source in broiler diet: Effect on growth performance, nutrient digestibility, and carcass and meat traits. Journal of Animal Science 2016, 94, 639-647, https://doi.org/10.2527/jas.2015-9201.

84. Yoo, J.S. et al. Nutrient ileal digestibility evaluation of dried mealworm (Tenebrio molitor) larvae compared to three animal protein by-products in growing pigs. Asian-Australasian journal of animal sciences 2019, 32, 387394, https://dx.doi.org/10.5713\%2Fajas.18.0647.

85. Benzertiha, A. et al. Tenebrio molitor and Zophobas morio full-fat meals as functional feed additives affect broiler chickens' growth performance and immune system traits. Poultry science 2020, 99, 196-206, https://doi.org/10.3382/ps/pez450.

86. Ghosh, S. et al. Nutritional composition of five commercial edible insects in South Korea. Journal of Asia-Pacific Entomology 2017, 20, 686-694, https://doi.org/10.1016/j.aspen.2017.04.003.

87. Ravzanaadii, N. et al. Nutritional value of mealworm, Tenebrio molitor as food source. International Journal of Industrial Entomology 2012, 25, 93-98, https://doi.org/10.7852/ijie.2012.25.1.093. 
88. Heidari-Parsa, S. Determination of yellow mealworm (Tenebrio molitor) nutritional value as an animal and human food supplementation. Arthropods 2018, 7, 94-102.

89. Ao, X. et al. Can dried mealworm (Tenebrio molitor) larvae replace fish meal in weaned pigs? Livestock Science 2020, 239, 104103, https://doi.org/10.1016/j.livsci.2020.104103.

90. Boulos, S.; Tännler, A.; Nyström, L. Nitrogen-to-Protein Conversion Factors for Edible Insects on the Swiss Market: T. molitor, A. domesticus, and L. migratoria. Frontiers in nutrition 2020, 7, 89, https://doi.org/10.3389/fnut.2020.00089.

91. Sedgh-Gooya, S. et al. Yellow mealworm, Tenebrio molitor (Col: Tenebrionidae), larvae powder as dietary protein sources for broiler chickens: Effects on growth performance, carcass traits, selected intestinal microbiota and blood parameters. Journal of Animal Physiology and Animal Nutrition 2021, 105, 119-128, https://doi.org/10.1111/jpn.13434.

92. Hussain, I. et al. Meal worm (Tenebrio molitor) as potential alternative source of protein supplementation in broiler. Int. J. Biosci 2017, 10, 225-262, http://dx.doi.org/10.12692/ijb/10.4.255-262.

93. Hong, J.; Han, T.; Kim, Y.Y. Mealworm (Tenebrio molitor Larvae) as an alternative protein source for monogastric animal: A review. Animals 2020, 10, 2068, https://doi.org/10.3390/ani10112068.

94. Montowska, M. et al. Nutritional value, protein and peptide composition of edible cricket powders. Food chemistry 2019, 289, 130-138, https://doi.org/10.1016/j.foodchem.2019.03.062.

95. Udomsil, N. et al. Nutritional values and functional properties of house cricket (Acheta domesticus) and field cricket (Gryllus bimaculatus). Food Science and Technology Research 2019, 25, 597-605, https://doi.org/10.3136/fstr.25.597.

96. Bawa, M. et al. Effect of diet on the growth performance, feed conversion, and nutrient content of the house cricket. Journal of Insect Science 2020, 20, 10, https://doi.org/10.1093/jisesa/ieaa014.

97. Finke, M.D. Complete nutrient composition of commercially raised invertebrates used as food for insectivores. Zoo Biology 2002, 21, 269-285, https://doi.org/10.1002/zoo.10031.

98. Finke, M.D. Complete nutrient content of four species of commercially available feeder insects fed enhanced diets during growth. Zoo biology 2015, 34, 554-564, https://doi.org/10.1002/zoo.21246.

99. Oonincx, D.G.A.B.; Dierenfeld, E.S. An investigation into the chemical composition of alternative invertebrate prey. Zoo Biology 2012, 31, 40-54, https://doi.org/10.1002/zoo.20382.

100. Finke, M.D. Complete nutrient content of three species of wild caught insects, pallid-winged grasshopper, rhinoceros beetles and white-lined sphinx moth. Journal of Insects as Food and Feed 2015, 1, 281-292, https://doi.org/10.3920/JIFF2015.0033.

101.Oonincx, D.G.A.B.; van der Poel, A.F.B. Effects of diet on the chemical composition of migratory locusts (Locusta migratoria). Zoo Biology 2011, 30, 9-16, https://doi.org/10.1002/zoo.20308.

102. Finke, M.D. Estimate of chitin in raw whole insects. Zoo Biology 2007, 26, 105-115, https://doi.org/10.1002/zoo.20123.

103.Bednářová, M.; Borkovcová, M.; Komprda, T. Purine derivate content and amino acid profile in larval stages of three edible insects. Journal of the Science of Food and Agriculture 2014, 94, 71-76, https://doi.org/10.1002/jsfa.6198.

104.Jin, X.H. et al. Supplementation of dried mealworm (Tenebrio molitor larva) on growth performance, nutrient digestibility and blood profiles in weaning pigs. Asian-Australasian Journal of Animal Sciences 2016, 29, 979986, https://doi.org/10.5713/ajas.15.0535.

105.Wu, R.A. et al. Comparison of the nutritional value of mysore thorn borer (Anoplophora chinensis) and mealworm larva (Tenebrio molitor): Amino acid, fatty acid, and element profiles. Food chemistry 2020, 323, 126818, https://doi.org/10.1016/j.foodchem.2020.126818.

106. Sushchik, N.N. et al. Comparison of fatty acid composition in major lipid classes of the dominant benthic invertebrates of the Yenisei river. Comparative Biochemistry and Physiology Part B: Biochemistry and Molecular Biology 2003, 134, 111-122, https://doi.org/10.1016/S1096-4959(02)00191-4.

107.Gladyshev, M.I. et al. Quantitative estimation of dragonfly role in transfer of essential polyunsaturated fatty acids from aquatic to terrestrial ecosystems. Doklady Biochemistry and biophysics 2011, 438, 141-143, https://doi.org/10.1134/S1607672911030094.

108.Zinchenko, T.D. et al. Saline rivers provide arid landscapes with a considerable amount of biochemically valuable production of chironomid (Diptera) larvae. Hydrobiologia 2014, 722, 115-128, https://doi.org/10.1007/s10750013-1684-5.

109.Zielińska, E. et al. Selected species of edible insects as a source of nutrient composition. Food Research International 2015, 77, 460-466, https://doi.org/10.1016/j.foodres.2015.09.008. 